\title{
Research of urban Female Fitness Status in Henan province
}

\author{
Lijuan Zhang \\ Department of Physical Education Research, Henan University of Traditional Chinese Medicine, \\ Boxue Road, East Jinshui Road, Zhengzhou City 450008,China
}

Keywords: Henan Province; City Women; Social culture; Sport Fitness.

\begin{abstract}
From the perspective of social cultural science and by using literature, questionnaire, mathematical statistics, logical reasoning and analytical methods, female sport fitness status in cities of Henan Province is analyzed and it shows that the awareness of women in our province for sport Fitness has been strengthened, but because of mutual effects of the status of the province's economic development, the negative impact of media , cultural traditions and social environment, urban female sport fitness in our province is not optimistic and there are still many problems. The article argue that the current health situation is effectively improved by increasing economic development and economic investment for physical fitness facilities, improving the legal system management, developing specific workable objectives and enhance education of family, school and society as well as positive media publicity and other means for developing tools and service systems for urban women sports activities in our province, opening up the majority of women thought , and improving the life quality of women in our province.
\end{abstract}

\section{Introduction}

Urban women are an important part of the female population in our province, and they are not only an important member of the family, but also are indispensable members of society to promote the economic development of our province. They play an important role for their family happiness and harmonious progress of the society. Our group investigate and analyze urban women fitness in Henan Province and explore social and cultural reasons of impacting urban female fitness in Henan province. To build a harmonious society and better implement the "National Fitness Program Outline" to make recommendations, we hope to provide the basis for sports administration in our province to make mass sports policies and development plans.

\section{Subjects and Methods}

\subsection{The study subjects}

Regarding 18 prefecture-level cities of Henan as the stratified sampling frame and actually extracting women of five cities-Chengdu, Panzhihua, Zigong, Luzhou, Leshan as the survey, s, we explore social and cultural reasons of urban Female Fitness in Henan Province by research and analysis of their fitness status.

\subsection{Research Methods}

\subsubsection{Literature}

Read the literature of urban female fitness related articles and community sports and sports sociology.

\subsubsection{Questionnaire}

The survey continued in five cities in Henan Province in October 2006 to April 2007. Definition of urban women mass sports Survey of is "the urban female mass sports and recreational activities except for school sports and armed forces," and the overall sample survey is "igreater than or equal to 16-year-old female population " in the province-level cities. The survey questionnaires were distributed 4000 , the effective recovery questionnaires are 3473 and the effective rate is $86.83 \%$ (some problems that respondents avoid and do not answer are calculated as "default" terms when accounting). 


\subsubsection{Mathematical statistics}

Statistics uses Spss statistical software for statistical analysis of the survey results.

\subsubsection{Logical reasoning}

The use of statistics results is to propose a solution with logical analysis of the current situation.

\section{Urban Women Physical Fitness status in Henan Province}

Henan Province is a populous province where economic development is lagging behind, personal monthly income and monthly household income was significantly below the national average. The average monthly gross income (see below) less than \$ 800 (including 800) in Henan province accounted for $51.00 \%$, and the total monthly family income (see Table 1) less than 1200 yuan (including 1200 yuan) accounted for about 33.36\%. China's National Bureau released Statistics that in 2006 national urban residents per capital disposable income is about 980 yuan, and compared with the case candidate of Panzhihua, Henan Province per capital disposable income ranked much lower than China's coastal cities. Generally low income levels severely affected urban women fitness development in our province.

Table 1 Family monthly income survey statistics

\begin{tabular}{|c|c|c|c|c|c|c|c|c|c|c|}
\hline $\begin{array}{c}\text { Family } \\
\text { monthly } \\
\text { gross } \\
\text { income }\end{array}$ & $\begin{array}{c}\text { Less } \\
\text { than400 }\end{array}$ & $\begin{array}{c}401 \\
-\end{array}$ & $\begin{array}{c}801 \\
-\end{array}$ & $\begin{array}{c}1201 \\
-\end{array}$ & $\begin{array}{c}1501 \\
-\end{array}$ & $\begin{array}{c}2001 \\
-\end{array}$ & $\begin{array}{c}3001 \\
-\end{array}$ & $\begin{array}{c}5001 \\
-\end{array}$ & $\begin{array}{c}\text { More } \\
\text { than }\end{array}$ & $\begin{array}{c}\text { Default } \\
\text { value }\end{array}$ \\
\hline number & 163 & 444 & 534 & 447 & 608 & 612 & 376 & 162 & 74 & 53 \\
\hline$\%$ & 4.77 & 12.98 & 15.61 & 13.07 & 17.78 & 17.89 & 10.99 & 4.74 & 2.16 & \\
\hline
\end{tabular}

Henan Province is located in southwest China, especially influenced by our traditional culture in the Southwest of china. To better facility feelings with others, the vast majority of urban women choose her family, colleagues, friends, neighbors to exercise together. In terms of family situation, very harmonious and relatively harmonious family accounted for $85.7 \%$, and most families are harmonious and get understanding and support of her family, (see Table 3) which undoubtedly provides a strong logistical support for the urban female fitness. They feel their physical condition as follows: better (40.28\%), general (38.07\%), very good (15.35\%), bad (5.59\%), very bad (0.72\%).

Table 2 the survey statistics of sports programs participated in

\begin{tabular}{|c|c|c|c|c|c|c|c|c|c|c|c|}
\hline No. & items & No. & $\%$ & No. & items & No. & $\%$ & No. & items & No. & $\%$ \\
\hline 1 & Walking & $\begin{array}{c}259 \\
4\end{array}$ & $\begin{array}{c}74.6 \\
9\end{array}$ & 9 & Table tennis & $\begin{array}{c}37 \\
3\end{array}$ & $\begin{array}{c}10.7 \\
4\end{array}$ & 17 & $\begin{array}{l}\text { Martial } \\
\text { Arts }\end{array}$ & 79 & 2.27 \\
\hline 2 & running & $\begin{array}{c}151 \\
8\end{array}$ & $\begin{array}{c}43.7 \\
1\end{array}$ & 10 & swimming & $\begin{array}{c}34 \\
3\end{array}$ & 9.88 & 18 & volleyball & 74 & 2.13 \\
\hline 3 & Badminton & $\begin{array}{c}112 \\
1\end{array}$ & $\begin{array}{c}32.2 \\
8\end{array}$ & 11 & dancing & $\begin{array}{c}35 \\
7\end{array}$ & $\begin{array}{c}10.2 \\
8\end{array}$ & 19 & football & 55 & 1.58 \\
\hline 4 & Skipping & 918 & $\begin{array}{c}26.4 \\
3\end{array}$ & 12 & Mountaineering & $\begin{array}{c}28 \\
6\end{array}$ & 8.23 & 20 & bowling & 45 & 1.30 \\
\hline 5 & stairs & 631 & $\begin{array}{c}18.1 \\
7\end{array}$ & 13 & yoga & $\begin{array}{c}20 \\
4\end{array}$ & 5.87 & 21 & croquet & 69 & 1.99 \\
\hline 6 & $\begin{array}{l}\text { Outside } \\
\text { sports }\end{array}$ & 615 & $\begin{array}{c}17.7 \\
1\end{array}$ & 14 & basketball & $\begin{array}{c}18 \\
7\end{array}$ & 5.38 & 22 & skating & 47 & 1.35 \\
\hline 7 & Shuttlecock & 595 & $\begin{array}{c}17.1 \\
3\end{array}$ & 15 & tai chi, sword & $\begin{array}{c}18 \\
8\end{array}$ & 5.41 & 23 & bicycle & $\begin{array}{c}87 \\
5\end{array}$ & $\begin{array}{c}25.1 \\
9\end{array}$ \\
\hline \multirow[t]{2}{*}{8} & aerobics & 657 & $\begin{array}{c}18.9 \\
2\end{array}$ & 16 & tennis & 84 & 2.42 & 24 & To book & 26 & 0.75 \\
\hline & & & & & & & & 25 & $\begin{array}{l}\text { Other } \\
\text { sports }\end{array}$ & 24 & 0.69 \\
\hline
\end{tabular}


Due to the constraints of city size, economic status and existing sports facilities space, Henan urban women in the choice of sports and fitness activities all regard the walking, running as the preferred project, followed by badminton, rope skipping, cycling, aerobics, stair climbing, outdoor sports, shuttlecock, etc. (See Table 2) Badminton with the restrictions of the site and equipment is widely welcomed by urban women with the selectivity rate of $32.28 \%$. "Affected by the mass media, female aesthetic consciousness and aesthetic standards of some cities in the province regard 'young, beautiful, gentle' as the fixed characteristics. Survey results showed that the" good physical shape "is the main purpose of the some young women involved in fitness training."[9] Aerobics as fitness means to enhance physical essence, improve physical function, promote the improvement of the body and enhance the beauty have been much welcomed by women, especially younger women. There are $45.87 \%$ women who chose "Likeness of physical exercise with no organization", highlighting common disadvantage of our province and national mass fitness exercise, and fitness activities are essentially spontaneous with lack of organization, management and guidance. They choose mostly fitness sites such as family and community parks nearby home and free sports venues with widespread dissatisfaction for the status of nearby fitness facilities. They sincerely want to get scientific fitness guide and increase fitness facilities located within the district.

Table 3 family support and household surveys Statistics

\begin{tabular}{|c|c|c|c|c|c|c|}
\hline $\begin{array}{c}\text { Family } \\
\text { support }\end{array}$ & $\begin{array}{c}\text { Very } \\
\text { support }\end{array}$ & $\begin{array}{c}\text { More } \\
\text { support }\end{array}$ & $\begin{array}{c}\text { General } \\
\text { support }\end{array}$ & $\begin{array}{c}\text { Not } \\
\text { support }\end{array}$ & $\begin{array}{c}\text { Very not } \\
\text { support }\end{array}$ & $\begin{array}{c}\text { Default } \\
\text { value }\end{array}$ \\
\hline No. & 1370 & 1352 & 681 & 52 & 10 & 8 \\
\hline$\%$ & 39.54 & 39.02 & 19.65 & 1.50 & 0.29 & 8 \\
\hline Family & harmonious & $\begin{array}{c}\text { More } \\
\text { harmonious }\end{array}$ & $\begin{array}{c}\text { General } \\
\text { harmonious }\end{array}$ & $\begin{array}{c}\text { Not } \\
\text { harmonious }\end{array}$ & $\begin{array}{c}\text { Very not } \\
\text { harmonious }\end{array}$ & $\begin{array}{c}\text { Default } \\
\text { value }\end{array}$ \\
\hline No. & 1859 & 1117 & 382 & 75 & 16 & 24 \\
\hline$\%$ & 53.90 & 32.39 & 11.08 & 2.17 & 0.46 & 24 \\
\hline
\end{tabular}

With economic development and people's living standards continue to improve, the requirements that urban women in our province pay attention to health and longevity are more urgent. "Health First", "quality of life" and other concepts is growing in popularity. The main purpose of their participation in physical exercise is to enhance physical fitness, health promotion. They relatively prefer physical fitness but don not believe that physical fitness is very important in life. But the sports awareness and ideas should be further improved, embodied in the exercise enthusiasm of women between the ages of 20-35 is not high and the motivation supporting the female population for physical exercise is mainly to lose weight, stylish, status symbol and other external motivation. Therefore, small population size is small but population mobility is large; middle-aged women have higher sports participation consciousness, but the concept of sports consumption is not strong and motivation supporting the majority of middle-aged women exercising is fitness and disease prevention, and their health concept is insufficient. The survey result shows that 1593 people like exercise with no organization, accounting for about $46 \%$. This fully shows that urban women in our province expect technical guidance in physical fitness, but also reflects the awareness of urban women in our province for scientific fitness is increased because they start from the blind participate to wish to obtain scientific fitness and high-quality fitness results . The survey found that urban women in our province who exercise more than once a week accounted for approximately 68.38\%, sports fitness training as a social culture has entered people's daily lives, and its popularity is growing year by year.

In general, the higher the educational level is, the stronger their participation in physical fitness and awareness is. Urban female in Henan Province less than college degree (excluding college degree) accounted for $64.03 \%$. Approximately $64.76 \%$ women surveyed do not know or have not heard of "National Fitness Program Outline." (See Table 4) The main factors impacting their participation in physical fitness are work and housework. Most urban women feel the relatively large pressure.

The current state of urban women sports fitness in Henan province is greatly influenced by the social and cultural impact of china, especially the Central Plains. Their Homelove is strong and focus 
on a harmonious atmosphere. Living in the same area of the community having certain organizational systems and cultural norms, they have a certain degree of identity and belonging. Survey results showed that 72.30 percents of life in the city has been more than a decade. They used to get up early to exercise and go out to exercise after family members or neighbors have dinner, and are accustomed to exercise together with family or neighbors, friends. The time that they insist to participate in physical exercise is in general not long.

Table 4 the survey statistics of degree and familiarity of "National Fitness Program"

\begin{tabular}{cccccccc}
\hline $\begin{array}{c}\text { Education } \\
\text { degree }\end{array}$ & $\begin{array}{c}\text { Junior } \\
\text { school and } \\
\text { blow }\end{array}$ & $\begin{array}{c}\text { High } \\
\text { school }\end{array}$ & $\begin{array}{c}\text { Secondary } \\
\text { school }\end{array}$ & college & $\begin{array}{c}\text { undergradu } \\
\text { ate }\end{array}$ & $\begin{array}{c}\text { Graduate } \\
\text { and over }\end{array}$ & $\begin{array}{c}\text { Default } \\
\text { value }\end{array}$ \\
\hline No. & 927 & 877 & 420 & 602 & 519 & 119 & 9 \\
$\%$ & 26.76 & 25.32 & 12.12 & 17.38 & 14.98 & 3.44 & \\
familiarity & very & more & general & Not much & No heard & & \\
No. & 93 & 295 & 836 & 1460 & 789 & & \\
$\%$ & 2.68 & 8.49 & 24.07 & 42.04 & 22.72 & & \\
\hline
\end{tabular}

\section{Conclusion and recommendations}

Changes of urban female cultural concepts in our province are affect by social productivity, the level of economic development. And the development of cultural concepts of women restricts he scope and extent of their participation in t sports and affecting ways of their participation in physical fitness. So urban woman of physical fitness in our province are more inclined to fitness programs that are simple and local with less requirements of technical and site conditions such as: walking, jogging, badminton, bicycles and other programs that are less affected by the economic field equipment, and different cities have slight difference with different ages and different occupational distribution. And the utilization of existing stadiums are not very high. They choose to exercise Locations based on residences and communities, parks, free sports venues nearby home. Therefore, the popularization of practical and effective fitness programs and opening greater openness of existing venues for the general public will help to improve enthusiasm of urban women's participation in sports fitness in our province.

Urban woman physical exercise in Henan province is impacted greatly by social culture of the central plains. Due to the daily routine of "early to rise and bed", the majority of them start their morning exercise activities before 7:30 o'clock in the morning and evening activities, and a relatively small population exercise in the morning and afternoon. In order to promote emotional communication with family, neighbors, friends, colleagues, they are accustomed to go out to exercise with family members, neighbors, friends, colleagues.

The physical Fitness concept has infiltrated the minds of the majority of the urban female population, but sports consciousness and sports concepts need to further improve. It shows mainly that physical exercise awareness of women between 20-35 years are not strong, and motivation that support the city's female population of the age in physical exercise is mainly weight loss, fashion, status symbol and other external motivation. Thus, small population size is small but mobility is large; consciousness that older women participate in sports is higher but the concept of sports consumption is not strong; motivation supporting the majority of middle-aged women in exercise is fitness and disease prevention and their lack of health concept.

School physical education is an important part to train consciousness of urban women exercise in our province and may establish different core objectives of physical activities at different stages of learning, promote the formation of proper physical exercise awareness, making fitness a part of life contents.

The Method that family physical Education can train urban family female physical exercise should be repeated and strengthened in daily life. The family is not the school, its role is not periodical and it can give influence in one's life. 
The family is the cell of society and the social impacts the family. Society should strive to create a physical exercise environment for each of the members to participate in. Society should fully support urban women in our province increase cultural knowledge and master the physical training methods, at the same time, it should also encourage popular sports activities, improve sports facilities, and strengthen the organization and management to create a good fitness atmosphere.

It full plays the functions of government administration and the media propaganda and mobilizes social forces to create a good atmosphere of fitness. We understand the real sport needs of urban women in our Province, work out mass sports development goals that can be regulated, specific and workable.

The relevant government departments coordinate actions, improve sports laws and regulations and increase enforcement of the sports laws and regulations. We should protect people's right to exercise and create favorable conditions for the vast female physical fitness. In addition, under the correct guidance of the relevant government departments, to carry out school district sport fitness activities by the effective use of school sports facilities is an effective model to solve the sport problems in our province.

\section{References}

[1] Jay Coakley (US). Sports Sociology [M] Beijing: Tinghua University Press, 2003.7.

[2] Wang kaizhen, Zhao Li. community sports [M] Beijing: Higher Education Press, 2004.7.

[3] Xu Fujun. The relation between female culture concept evolution and women's sports in china [J] .2001.5 1-2.

[4] Zhang Yongjun. Analysis of fitness concept of young adults in our Province from Sociological Perspective [J]. Shandong Sports Science, 1997.12 67-68.

[5] Jin Yuqiang, Liu Ying, Yang Zhiwei, etc. Sociological research about social status of women in China and Japan, leisure time and sports life [J] Proceedings of Beijing Sport University, 2002.3 155-156.

[6] Tang Donghui, Zhang Wenyu. Reflections about the female sports culture under the contemporary media discourse [J] sports and science, 2005.12 22-23.

[7] Chen Changli, Gao Honghui. The comparative study between chinese and western sport values for Chinese development implications [J] sports and science, 2007.1 65-66.

[8] Jiang XiuZhi, Han Ertao .On the Development Strategy of Women Leisure Sports [J] 2005.12: 34-35.

[9] Ding XiuJuan, Wu Chao. The sociology analysis of formation of urban women sports value in china [J] Proceedings of Shandong Institute of Physical Education, 2003, 9: 19-20.

[10]Tang Xiaoling. The sociology analysis of the motivation influencing old physical Exercise [J] Proceedings of Chengdu PE Institute, 2000.4: 31-32. 